\title{
PERENCANAAN PENUNTASAN WAJIB BELAJAR DAN PENINGKATAN MUTU PENDIDIKAN
}

\author{
Fatkhul Mubin \\ fatkhulmubin90@gmail.com
}

\begin{abstract}
ABSTRAKSI
Pendidikan merupakan salah satu unsur terpenting dalam pembangunan nasional, karena dengan adanya pendidikan bagi masyarakat akan menjadikan masyarakat lebih maju dalam pemikirannya. Pemikiran masyarakat yang maju akan membentuk Sumber Daya Manusia (SDM) yang berkualitas tinggi. Pendidikan juga tidak lepas dari peran pemerintah. Pemerintah mengutamakan pentingnya pendidikan bagi seluruh masyarakat dengan meningkatkan mutu pendidikan. Oleh karena itu, pemerintah berkewajiban untuk memenuhi hak setiap warga negara dalam memperoleh layanan pendidikan guna meningkatkan kualitas hidup bangsa Indonesia.

Kepedulian pemerintah dalam mewujudkan pendidikan yang lebih berkualitas diawali dari adanya program pendidikan yang bermutu. Salah satu kebijakan tersebut adalah adanya program pendidikan wajib belajar 9 tahun.
\end{abstract}

\section{PENDAHULUAN}

Upaya peningkatan sumber daya manusia yang utama dilakukan melalui pembangunan sektor pendidikan, seperti yang dinyatakan oleh Becker bahwa pendidikan merupakan faktor yang penting dalam pengembangan sumber daya manusia. Pendidikan tidak saja menambah pengetahuan, akan tetapi juga meningkatkan keterampilan bekerja yang akhirnya akan meningkatkan produktivitas kerja (Becker, 1994). Pengalaman empiris telah membuktikan bahwa bangsa-bangsa yang telah menikmati kesejahteraan dan kemakmuran bagi rakyatnya adalah bangsa yang memulai pembangunannya melalui pendidikan meskipun tidak memiliki sumber daya alam. Dengan sumber daya manusia yang berkualitas serta menguasai ilmu pengetahuan dan teknologi, bangsa tersebut dapat menikmati kemakmuran bangsanya. ${ }^{1}$

1 Saihu, S. (2019). RINTISAN PERADABAN PROFETIK UMAT MANUSIA MELALUI PERISTIWA TURUNNYA ADAM AS KE-DUNIA. Mumtaz: Jurnal Studi Al-Quran dan Keislaman, 3(2), 268-279,

Saihu, S. (2019). Pendidikan Pluralisme Agama: Kajian tentang Integrasi Budaya dan Agama dalam Menyelesaikan Konflik Sosial Kontemporer. Jurnal Indo-Islamika, 9(1), 67-90, 
Program wajib belajar sembilan tahun merupakan kebijakan pemerintah di dalam memperbaiki kualitas sumber daya manusia Indonesia agar memiliki standar pendidikan minimal sembilan tahun sebagai modal dasar pembangunan bangsa dalam meningkatkan pertumbuhan ekonomi melalui peningkatan produktivitas kerja tenaga terdidik di masa datang sekaligus mempersiapkan masyarakat agar mampu bersaing di pasar global. Program wajib belajar sembilan tahun didasari konsep "pendidikan dasar untuk semua"(universal basic education), yang pada hakekatnya berarti penyediaan akses yang sama untuk semua anak (Daliyo, 1998). Tujuan yang ingin dicapai dengan program ini adalah merangsang aspirasi pendidikan orang tua dan anak yang pada gilirannya diharapkan dapat meningkatkan produktivitas kerja penduduk secara nasional. ${ }^{2}$

Hasil Susenas sebagian besar masyarakat tidak mengikuti kegiatan persekolahan karena tidak adanya biaya. Hal ini menunjukkan bahwa faktor biaya pendidikan merupakan unsur utama dalam penuntasan wajib belajar sembilan tahun dan peningkatan mutu pembelajaran. Padahal wajib belajar sembilan tahun juga merupakan amanat Undang-undang Nomor 20 Tahun 2003 tentang Sistem Pendidikan Nasional yang mewajibkan negara menanggung biayanya.

Dunia pendidikan mengalami perkembangan yang luar biasa pesatnya, termasuk di Indonesia. Olive Blank (1971) menyebutnya sebagai "eksplosion of education" atau ledakan pendidikan. Di samping perkembangan kuantitatif, juga

Saihu, S. (2019). IMPLEMENTASI MANAJEMEN BALANCED SCORECARD DI PONDOK PESANTREN JAM'IYYAH ISLAMIYYAH TANGERANG SELATAN. Mumtaz: Jurnal Studi Al-Quran dan Keislaman, 3(1), 1-22.

Saihu, S. (2019). KOMUNIKASI PENDIDIK TERHADAP ANAK BERKEBUTUHAN KHUSUS DI SEKOLAH KHUSUS ASY-SYIFA LARANGAN. Andragogi: Jurnal Pendidikan Islam dan Manajemen Pendidikan Islam, 1(3), 418-440.

Saihu, S., \& Marsiti, M. (2019). PENDIDIKAN KARAKTER DALAM UPAYA MENANGKAL RADIKALISME DI SMA NEGERI 3 KOTA DEPOK, JAWA BARAT. Andragogi: Jurnal Pendidikan Islam dan Manajemen Pendidikan Islam, 1(1), 23-54.

Saihu, S. (2019). KONSEP MANUSIA DAN IMPLEMENTASINYA DALAM PERUMUSAN TUJUAN PENDIDIKAN ISLAM MENURUT MURTADHA MUTHAHHARI. Andragogi: Jurnal Pendidikan Islam dan Manajemen Pendidikan Islam, 1(2), 197-217.

Saihu, S., \& Rohman, B. (2019). PEMBENTUKAN KARAKTER MELALUI MODEL PENDIDIKAN TRANSFROMATIFE LEARNING PADA SANTRI DI PONDOK PESANTREN NURUL IKHLAS BALI. Edukasi Islami: Jurnal Pendidikan Islam, 8(02), 435-452.

${ }^{2}$ Muhamad Husin, "Penuntasan Wajib Belajar 12 Tahun di Provinsi DKI Jakarta" Jurnal Pendidikan dan Kebudayaan: Vol. 16, Nomor 1, Januari 2010. 
terjadi perkembangan kualitatif melalui perluasan dan pendalaman kurikulum serta perkembangan sikap positif masyarakat terhadap pendidikan, baik pendidikan formal, informal, maupun nonformal. ${ }^{3}$

\section{PEMBAHASAN}

\section{A. Penuntasan Wajib Belajar Pendidikan Dasar}

Wajib Belajar Pendidikan Dasar (Wajar Dikdas) Sembilan Tahun, tentang Sistem Pendidikan Nasional adalah jaminan pemerintah dan pemerintah daerah bagi setiap warga negara yang sudah berusia enam tahun untuk memperoleh pelayanan pendidikan, minimal pada jenjang Pendidikan Dasar tanpa dipungut biaya. Wajar Dikdas 9 tahun meliputi jenjang pendidikan SD, MI, SMP, MTs.M

Wajib Belajar adalah program respons pemerintah terhadap amanat konstitusi yang dituangkan dalam aneka peraturan dan program pemerintah yang intinya adalah bahwa Pendidikan ditetapkan sebagai salah satu prioritas dalam agenda utama pembangunan nasional, yakni sebagai berikut: ${ }^{4}$

\section{a. Amanat Pembukaan Undang-Undang Dasar (UUD) 1945:}

"Melindungi segenap bangsa Indonesia dan seluruh tumpah darah Indonesia dan untuk memajukan kesejahteraan umum, mencerdaskan kehidupan bangsa, dan ikut melaksanakan ketertiban dunia...”.

\section{b. Amanat Pasal 31 UUD 1945}

a) Setiap warga Negara berhak mendapatkan pendidikan;

b) Setiap warga Negara wajib mengikuti Pendidikan Dasar dan pemerintah wajib membiayaninya

c) Pemerintah mengusahakan dan menyelenggarakan satu Sistem Pendidikan Nasional, yang meningkatkan keimanan dan ketakwaan serta akhlak mulia dalam rangka mencerdaskan kehidupan bangsa, yang diatur oleh undang undang;Negara memprioritaskan anggaran pendidikan sekurang-kurangnya

${ }^{3}$ Manap Somantri, "PENCANAAN PENDIDIKAN", (Bogor: PT Penerbit IPB Press Kampus IPB Taman Kencana, 2014), h.49.

${ }^{4}$ Rina Yulianti dan Titi Stiawati, "Penuntasan Wajib Belajar Pendidikan Dasar Sembilan Tahun Oleh Pemerintah Daerah” IJurnal Ilmiah Niagara Vol. VII No. 1, Juni 2014. 
$20 \%$ dari APBN serta dari APBD untuk memenuhikebutuhan penyelenggaraan pendidikan nasional;

d) Pemerintah memajukan ilmu pengetahuan dan teknologi dengan menjunjung tinggi nilai-nilai agama dan persatuan bangsa untuk kemajuan peradaban serta kesejahteraan umat manusia;

e) Pemerintah memajukan ilmu pengetahuan dan teknologi dengan menjunjung tinggi nilai-nilai agama dan persatuan bangsa untuk kemajuan peradaban serta kesejahteraan umat manusia;

f) Amanat Undang-undang No: 20 Tahun 2003 tentang Sistem Pendidikan Nasional. Peraturan Pemerintah No. 25 tahun 2005 tentang Rencana Pembangunan Jangka Menengah Nasional (RPJMN) 2004-2009.

Selain amanat Undang-undang, pada dasarnya program wajib belajar merupakan tuntutan perubahan karena didasari konsep "pendidikan dasar untuk semua"(universal basic education), yang pada hakekatnya berarti penyediaan akses yang sama untuk semua anak (Daliyo, 1998). Dengan penyediaan akses yang sama bagi semua anak, maka setiap anak akan memperoleh peningkatan kemampuan bersaing dalam iklim gobal. Dengan demikian program wajib belajar bertujuan untuk memberikan bekal kemampuan dasar kepada peserta didik untuk mengembangkan kehidupannya sebagai pribadi, anggota masyarakat, warga negara dan anggota umat manusia serta mempersiapkan peserta didik untuk mengikuti pendidikan menengah. ${ }^{5}$

${ }^{5}$ Saihu, S., \& Taufik, T. (2019). PERLINDUNGAN HUKUM BAGI GURU. Al Amin: Jurnal Kajian Ilmu dan Budaya Islam, 2(2), 105-116.

Saihu, S. (2020). KONSEP PEMBAHARUAN PENDIDIKAN ISLAM MENURUT FAZLURRAHMAN. Andragogi: Jurnal Pendidikan Islam dan Manajemen Pendidikan Islam, 2(1), 82-95.

Saihu, S. (2020). ETIKA MENUNTUT ILMU MENURUT KITAB TA'LIM MUTA'ALIM. Al Amin: Jurnal Kajian Ilmu dan Budaya Islam, 3(1), 99-112.

Saihu, Aziz, A., Mubin, F., \& Sarnoto, A. Z. (2020). Design of islamic education based on local wisdom (An analysis of social learning theories in forming character through ngejot tradition in bali). International Journal of Advanced Science and Technology, 29(6), 1278-1293.

Ronaldo, R., Zulfikar, A., Saihu, Ismail, \& Wekke, I. S. (2020). International relations of the asia pacific in the age of trump. Journal of Environmental Treatment Techniques, 8(1), 244-246.

Saihu, M. M., \& Aziz, A. (2020). Implementasi Metode Pendidikan Pluralisme Dalam Mata Pelajaran Pendidikan Agama Islam. Belajea; Jurnal Pendidikan Islam, 5(1), 131-150.

Saihu, M. (2019). Urgensi 'Urf dalam Tradisi Male dan Relevansinya dalam Dakwah Islam di Jembrana-Bali. Jurnal Bimas Islam, 12(1), 173-201. 
Program wajib belajar sembilan tahun diIndonesia di mulai pencanangannya pada tahun 1994 dan ditargetkan penuntasannya pada tahun 2008 (Harian Kompas, 29 November 2005). Ada lima alasan bagi pemerintah untuk memulai program wajib belajar sembilan tahun: (1) lebih dari 80 persen angkatan kerja hanya berpendidikan SD atau kurang, atau SMP tidak tamat; (2) program wajib belajar sembilan tahun akan meningkatkan kualitas SDM dan dapat memberi nilai tambah pada pertumbuhan ekonomi; (3) semakin tinggi pendidikan akan semakin besarpartisipasi dan kontribusinya di sektor-sektor yang produktif; (4) dengan peningkatan program wajib belajar dari enam ke sembilan tahun, akan meningkatkan kematangan dan ketrampilan siswa; (5) peningkatan wajib belajar menjadi sembilan tahun akan meningkatkan umur kerja minimum dari 10 ke 15 tahun (Daliyo, 1998). ${ }^{6}$

Kebijakan wajib belajar pendidikan dasar masih menghadapi masalah dan tantangan yang amat berat. Oleh karena itu diperlukan adanya upaya yang sistematis dan terarah untuk jangka panjang dalam manajemen waktu, biaya, tenaga, dan sumber-sumber lainnya. Di sinilah peranan perencanaan strategis dalam penanganan wajib belajar.

\section{B.Indikator Penuntasan Wajib Belajar}

Indikator pencapaian program wajib belajar adalah kinerja pencapaian Angka Partisipasi Kasar (APK) dan Angka Partisipasi Murni (APM) untuk jenjang pendidikan SD sampai SMP sebesar 90\% (Bank Dunia, 2004). Angka Partisipasi Kasar (APK) adalah persentase jumlah siswa seluruhnya terhadap jumlah penduduk usia sekolah pada jenjang tertentu. APK dihitung dengan rumus:

(Jumlah siswa seluruhnya)

$\mathrm{APK}=$ $\mathrm{X} 100 \%$

(Jumlah penduduk usia 7-15)

Saihu, S. (2020). The Effect of Using Talking Stick Learning Model on Student Learning Outcomes in Islamic Primary School of Jamiatul Khair, Ciledug Tangerang. Tarbawi: Jurnal Keilmuan Manajemen Pendidikan, 6(01), 61-68.

Saihu, S. (2020). Pendidikan sosial yang terkandung dalam Surat At-Taubah Ayat 71-72. Edukasi Islami: Jurnal Pendidikan Islam, 9(01), 127-148.

${ }^{6}$ Muhamad Husin, “Penuntasan Wajib Belajar 12 Tahun di Provinsi DKI Jakarta” Jurnal Pendidikan dan Kebudayaan: Vol. 16, Nomor 1, Januari 2010 
Angka Partisipasi Murni (APM) adalah persentase jumlah siswa usia sekolah terhadap jumlah penduduk usia sekolah pada suatu jenjang sekolah, usia sekolah pendidikan dasar adalah 7-15 Tahun. Besarnya APM dihitung dengan rumus:

(Jumlah siswa usia 7-15)

$\mathrm{APM}=\frac{\mathrm{X} 100 \%}{(\text { Jumlah penduduk usia 7-15) }}$
( s u m b e r : w w w. d e p di k n a s.g o. i d / d i t j e n manajemendikdasmen)

Berdasarkan laporan Bank Dunia tahun 2004 Indonesia masih belum mampu memenuhi program wajib belajar sembilan tahun bagi semua anak, karena masih terdapat sekitar 20 persen anak usia sekolah menengah pertama yang masih belum bersekolah (Bank Dunia, 2004). Krisis ekonomi yang melanda Indonesia berpengaruh terhadap APK dan APM pendidikan dasar. ${ }^{7}$

Program BOS yang dimulai pada tahun 2005 telah berperan dalam percepatan pencapaian program wajib belajar. Oleh karena itu mulai tahun 2009, pemerintah melakukan perubahan tujuan, pendekatan, dan orientasi. Program BOS ke depan bukan hanya berperan untuk mempertahankan APK, tetapi harus juga berkontribusi penting untuk peningkatan mutu pendidikan. Selain itu dengan biaya satuan BOS yang telah dinaikkan secara signifikan, program ini akan menjadi pilar utama untuk mewujudkan pendidikan gratis di pendidikan dasar. ${ }^{8}$

\section{Strategi Pelaksanaan Wajib Belajar}

Strategi pelaksanaan Wajib Belajar 9 Tahun di Indonesia, saat ini, dilaksanakan dengan menerapkan beberapa pendekatan, meliputi: pendekatan budaya, pendekatan sosial, pendekatan agama, pendekatan birokrasi, pendekatan hukum, serta pendekatan konteks. ${ }^{9}$

a. Pendekatan Budaya

${ }^{7}$ Ibid, h. 95 .

${ }^{8}$ Manap Somantri, “PENCANAAN PENDIDIKAN”, (Bogor: PT Penerbit IPB Press Kampus IPB Taman Kencana, 2014), h.53.

${ }^{9}$ Asroni Paslah, "Pencapaian Program Wajib Belajar 9 Tahun" (https://www.kompasiana.com/asronyfaslah/55008159a33311240d50f8d1/pencapaian-programwajib-belajar-9-tahun, di akses pada 9 April 2020, 2020). 
Sosialisasi wajib belajar dilakukan dengan memanfaatkan budaya yang berkembang di daerah tersebut; misalnya daerah yang masyarakatnya senang dengan seni, maka pesan-pesan wajib belajar dapat disisipkan pada gelar seni. Masyarakat yang sangat menghormati adat, maka tokoh adat dilibatkan dalam pemikiran dan pelaksanaan sosialisasi Wajar Dikdas sembilan tahun yang bermutu. Sanksi adat biasanya lebih disegani daripada sanksi hukum. ${ }^{10}$

b. Pendekatan Sosial

Sosialisasi Wajar Dikdas sembilan tahun yang bermutu perlu memperhatikan kondisi sosial ekonomi masyarakat. Bila dalam masyarakat ada tokoh yang disegani dan bisa menjadi panutan, maka tokoh ini perlu dilibatkan dalam sosialisasi. Tokoh masyarakat ini bisa berasal dari tokoh formal, maupun tokoh non formal. Pada masyarakat ekonomi lemah, sosialisasi dilakukan dengan memberikan informasi tentang pelayanan pemerintah untuk pendidikan, misalnya BOS ataupun beasiswa. Bila anak sibuk membantu kerja orangtua, anak tidak harus berhenti bekerja, tetapi disampaikan jenis pendidikan alternatif yang bisa diikuti oleh anak yang bersangkutan, misalnya SMP Terbuka atau program Paket B.

c. Pendekatan Agama

10 Aziz, A., \& Saihu, S. (2019). Interpretasi Humanistik Kebahasaan: Upaya Kontekstualisasi Kaidah Bahasa Arab. Arabiyatuna: Jurnal Bahasa Arab, 3(2), 299-214

Saihu, S. (2019). PENDIDIKAN KARAKTER BERBASIS KEARIFAN LOKAL (STUDI DI JEMBRANA BALI). Edukasi Islami: Jurnal Pendidikan Islam, 8(01), 69-90.

Şahin, C. RELIGIA.

Saihu, S., \& Mailana, A. (2019). Teori pendidikan behavioristik pembentukan karakter masyarakat muslim dalam tradisi Ngejot di Bali. Ta'dibuna: Jurnal Pendidikan Islam, 8(2), 163-176.

Mubin, F. KEADILAN DALAM GENDER: KAJIAN KEPEMIMPINAN WANITA DALAM ISLAM1,

Saihu, M. (2019). Merawat Pluralisme Merawat Indonesia (Potret Pendidikan Pluralisme Agama Di Jembrana-Bali). Deepublish.

Mubin, F. (2019). TAFSIR EMANSIPATORIS: PEMBUMIAN METODOLOGI TAFSIR PEMBEBASAN. Mumtaz: Jurnal Studi Al-Quran dan Keislaman, 3(1), 131-151.

Mubin, F. MODEL-MODEL PEMBELAJARAN BERBASIS MADRASAH DAN KEGIATAN LAIN YANG DIPERLUKAN DI DALAMNYA (FAKTOR PENDUKUNGNYA). 
Pada daerah tertentu ada yang masyarakatnya sangat agamis dan sangat mentaati ayat-ayat suci. Untuk daerah seperti ini peran para tokoh agama sangat sesuai. Dengan mengutip ayat-ayat suci, maka konsep wajib belajar lebih mudah diikuti. Untuk ini motto "belajar adalah ibadah" yang didasarkan atas kajian yang sangat mendalam oleh para tokoh agama dapat diangkat menjadi motto dalam sosialisasi Wajar Dikdas sembilan tahun yang bermutu.

d. Pendekatan Birokrasi

Pendekatan birokrasi ialah upaya memanfaatkan sistem pemerintahan, baik di tingkat pusat maupun daerah. Pembentukan tim koordinasi di tingkat pusat, provinsi, kabupaten/kota, dan kecamatan merupakan salah satu bentuk pendekatan birokrasi. Birokrasi ditempuh karena dengan pendekatan ini lebih mudah diperoleh berbagai faktor penunjang baik tenaga, sarana, maupun dana. Namun demikian pendekatan ini akan lebih berhasil bila digabung dengan pendekatan yang lain.

e. Pendekatan Hukum

Pendekatan hukum ialah pendekatan yang hanya digunakan untuk daerah yang masyarakatnya memiliki kesadaran terhadap pendidikan sangat rendah dan tingkat resistensinya tinggi.

Program Wajib Belajar Sembilan Tahun sampai saat ini masih memberlakukan konsep "universal basic education" dan belum menerapkan konsep “compulsary education”. Artinya, program wajib belajar baru sebatas himbauan tanpa diikuti sanksi hukum. Namun jika diperlukan, UU Nomor 20 tahun 2003, memberi kemungkinan kepada pemerintah untuk menerapkan konsep “compulsary education", sehingga berkonsekuensi adanya sanksi hukum bagi yang tidak mau melaksanakan tanggung jawabnya terhadap program wajib belajar, baik pemerintah, pemerintah daerah, orangtua, maupun peserta didik. ${ }^{11}$

\section{Hambatan dalam Pelaksanaan Program Wajib Belajar}

${ }^{11}$ Direktorat Pembinaan SMP, Panduan Pelaksanaan Gerakan Nasional Percepatan penuntasan Wajib Belajar 9 Tahun dan Pemberantasan Buta Aksara, (Departemen Pendidikan Nasional, 2008) h. 27 
Keberhasilan Program Wajib Belajar, menurut Sukardi (2010) dapat dibagi menjadi 2 faktor, yaitu: faktor internal dan faktor eksternal. Faktor internal merupakan faktor yang dipengaruhi dari dalam individu. Faktor internal, meliputi: kemampuan anak, minat sekolah, ekspektasi (harapan) anak, persepsi siswa tentang sekolah dan aspirasi/ cita-cita anak. Faktor eksternal yang dipengaruhi oleh keadaan dari luar individu tersebut, meliputi: kondisi geografis, kondisi sosial ekonomi, keutuhan keluarga, persepsi orang tua, dan ketersedian sarana prasarana. ${ }^{12}$

Penelitian Abdillah (2010) menyebutkan bahwa permasalahan dalam program wajib belajar, antara lain: tingkat pendidikan orang tua mempunyai angka partisipasi yang rendah, mata pencaharian/pekerjaan dan pendapatan orang tua mempunyai angka partisipasi yang sangat rendah, karakteristik keluarga berperan dalam penuntasan program wajib belajar. ${ }^{13}$

angka partisipasi lingkungan tempat tinggal rendah, kesadaran orang tua tentang pentingnya pendidikan terhitung rendah, faktor aksesibilitas tidak terlalu menjadi suatu masalah.

\section{E. Peningkatan Mutu}

Mutu secara etimologis bersinonim dengan kata 'kualitas, bobot, derajat, jenis, karat, kadar, kelas, nilai, taraf'. ${ }^{14}$ Dengan kata lain, mutu adalah kondisi (kualitas, bobot, derajat, dst) barang atau jasa yang dihasilkan dari sebuah proses. Batasan mutu biasanya diserta deskripsi proses produksi untuk menghasilkan barang atau jasa tersebut.

Pembahasan tentang mutu biasanya tidak dilepaskan dari tonggak sejarah yang menempatkan mutu sebagai esensi utama yang harus dipertimbangkan dari sebuah rencana kerja (produksi). Dalam bidang pendidikan Juran menegaskan bahwa dasar misi mutu sebuah sekolah adalah "mengembangkan program dan layanan yang memenuhi kebutuhan pengguna seperti siswa dan masyarakat".

Lewis dan Smith secara lebih rinci menterjemahkan bahwa mutu secara keseluruhan (total quality), termasuk dalam bidang pendidikan, mencakupi tiga

\footnotetext{
${ }^{12}$ Laelia Nurpratiwiningsih, Skripsi: "Pelaksanaan Program Wajib Belajar 9 Tahun di Kecamatan Kedung banteng Kabupaten Tegal” ( Tegal: UNS, 2011), H.24

13 Ibid

${ }^{14}$ Pusat Bahasa, Tesaurus Bahasa Indonesia, (Jakarta: Depdiknas, 2008) h. 331
} 
ranah yang wajib diperhatikan yaitu: seluruh proses, seluruh pekerjaan, dan seluruh personil yang terlibat. ${ }^{15}$ Pertama, total quality mencakup seluruh proses, bukan hanya proses produksi semata. Di dalamnya juga harus tercakup pengembangan proses perancangan, pembangunan, penelitian dan pengembangan, akunting, pemasaran, layanan perbaikan, dan seluruh fungsi lainnya. Kedua, total quality menghendaki dilaksanakannya setiap pekerjaan yang terkait dalam proses secara prima (profesional). Ketiga, total quality menghendaki semua orang yang terlibat dalam pekerjaan bertanggung jawab atas kualitas pekerjaan yang menjadi tugasnya.

Dalam bidang pendidikan, untuk bisa menghasilkan mutu, terdapat empat usaha mendasar yang harus dilakukan dalam suatu lembaga pendidikan, yaitu : ${ }^{16}$

1. Menciptakan situasi (win-win solution). Dalam hal ini terutama antara pimpinan lembaga dengan staf lembaga harus terjadi kondisi yang saling menguntungkan satu sama lain dalam meraih mutu produk/jasa yang dihasilkan oleh lembaga pendidikan tersebut.

2. Perlunya ditumbuhkembangkan motivasi instrinsik pada setiap orang yang terlibat dalam proses meraih mutu. Setiap orang dalam lembaga pendidikan harus tumbuh motivasi bahwa hasil kegiatannya mencapai mutu tertentu yang meningkat terus menerus, terutama sesuai dengan kebutuhan dan harapan pengguna/langganan.

3. Setiap pimpinan harus berorientasi pada proses dan hasil jangka panjang. Penerapan manajemen mutu terpadu dalam pendidikan bukanlah suatu proses perubahan jangka pendek, tetapi usaha jangka panjang yang konsisten.

4. Dalam menggerakkan segala kemampuan lembaga pendidikan untuk mencapai mutu yang ditetapkan, harus dikembangkan adanya kerjasama antar unsur-unsur pelaku proses mencapai hasil mutu.

\footnotetext{
${ }^{15}$ Gumolo, “Permasalahan Mutu Dalam Wajib Belajar Pendidikan Dasar 9Tahun", (https://gumonounib.wordpress.com/2010/09/19/permasalahan-mutu-dalam-wajib-belajar pendidikan-dasar-9-tahun/, di akses pada 9 April 2020, 2020). ${ }^{16}$ Ibid
} 
Menurut sardi mengenai mutu pendidikan terdapat standar mutu pendidikan sesuai ISO 9001 : 2008 adalah sebagai beikut: ${ }^{17}$
a. Komponen standar isi
b. Komponen standar proses
c. Komponen standar kompetensi lulusan
d. Komponen standar pendidik dan kependidikan
e. Komponen standar sarana dan prasarana
f. Komponen standar pengelolaan
g. Komponen standar pembiayaan
h. Komponen standar penilaian.

\section{PENUTUP}

\section{KESIMPULAN}

Pendidikan merupakan tanggung jawab bersama tidak bisa dibebankan kesalah satu pihak. Pendidikan yang dilandasi oleh kebersamaan dalam penyelenggaraannya akan terjamin keberlangsungan, mutu serta hasil dari pada proses belajar mengajar yang diharapkan. Masyarakat selaku pengguna jasa lembaga pendidikan memiliki kewajiban untuk mengembangkan serta menjaga keberlangsungan penyelenggaraan proses pendidikan. Selain itu, Program ini mewajibkan setiap warga negara Indonesia untuk bersekolah selama 9 (sembilan) tahun pada jenjang pendidikan dasar, yaitu dari tingkat kelas 1 Sekolah Dasar (SD) atau Madrasah Ibtidaiyah (MI) hingga kelas 9 Sekolah Menengah Pertama (SMP) atau Madrasah Tsanawiyah(MTs).

Begitu juga dengan pemerintah khususnya pemerintah daerah dimana mereka harus lebih memperhatikan kondisi pendidikan tidak hanya mewajibkan sembilan tahun pendidikan dasar tanpa di tunjang dengan sarana dan prasarana yang memadai. Sudah sepatutnya negara kita memperhatikan pendidikan tidak hanya mewajibkan sembilan tahun pendidikan dasar tanpa di tunjang dengan sarana dan prasarana

\footnotetext{
${ }^{17}$ (http://repository.radenintan.ac.id/158/3/Bab_II.pdf, di akses pada 9 April 2020,2020)
} 
yang memadai. Sudah sepatutnya negara kita memperhatikan dan melaksanakan apa yang menjadi hak warganegara untuk memperoleh pendidikan yang layak.dan melaksanakan apa yang menjadi hak warganegara untuk memperoleh pendidikan yang layak.

\section{DAFTAR PUSTAKA}

(http://repository.radenintan.ac.id/158/3/Bab_II.pdf,

(https://www.kompasiana.com/asronyfaslah/55008159a33311240d50f8d1/pencap aian-program-wajib-belajar-9-tahun,

Aziz, A., \& Saihu, S. (2019). Interpretasi Humanistik Kebahasaan: Upaya Kontekstualisasi Kaidah Bahasa Arab. Arabiyatuna: Jurnal Bahasa Arab, 3(2), 299-214

Direktorat Pembinaan SMP, Panduan Pelaksanaan Gerakan Nasional Percepatan penuntasan Wajib Belajar 9 Tahun dan Pemberantasan Buta Aksara, (Departemen Pendidikan Nasional, 2008)

https://gumonounib.wordpress.com/2010/09/19/permasalahan-mutu-dalam-wajibbelajar pendidikan-dasar-9-tahun/

Laelia Nurpratiwiningsih, Skripsi: "Pelaksanaan Program Wajib Belajar 9 Tahun di

Kecamatan Kedung banteng Kabupaten Tegal” ( Tegal: UNS, 2011),

Manap Somantri, "PENCANAAN PENDIDIKAN”, (Bogor: PT Penerbit IPB Press

Kampus IPB Taman Kencana, 2014)

Mubin, F. (2019). TAFSIR EMANSIPATORIS: PEMBUMIAN METODOLOGI TAFSIR PEMBEBASAN. Mumtaz: Jurnal Studi Al-Quran dan Keislaman, 3(1), 131-151.

Mubin, F. KEADILAN DALAM GENDER: KAJIAN KEPEMIMPINAN WANITA DALAM ISLAM1,

Mubin, F. MODEL-MODEL PEMBELAJARAN BERBASIS MADRASAH DAN KEGIATAN LAIN YANG DIPERLUKAN DI DALAMNYA (FAKTOR PENDUKUNGNYA).

Muhamad Husin, "Penuntasan Wajib Belajar 12 Tahun di Provinsi DKI Jakarta"

Jurnal Pendidikan dan Kebudayaan: Vol. 16, Nomor 1, Januari 2010.

Pusat Bahasa, Tesaurus Bahasa Indonesia, (Jakarta: Depdiknas, 2008)

Rina Yulianti dan Titi Stiawati, "Penuntasan Wajib Belajar Pendidikan Dasar

Sembilan Tahun Oleh Pemerintah Daerah” IJurnal Ilmiah Niagara Vol. VII No.

1, Juni 2014. 
Ronaldo, R., Zulfikar, A., Saihu, Ismail, \& Wekke, I. S. (2020). International relations of the asia pacific in the age of trump. Journal of Environmental Treatment Techniques, 8(1), 244-246.

Şahin, C. RELIGIA.

Saihu, Aziz, A., Mubin, F., \& Sarnoto, A. Z. (2020). Design of islamic education based on local wisdom (An analysis of social learning theories in forming character through ngejot tradition in bali). International Journal of Advanced Science and Technology, 29(6), 1278-1293.

Saihu, M. (2019). Urgensi 'Urf dalam Tradisi Male dan Relevansinya dalam Dakwah Islam di Jembrana-Bali. Jurnal Bimas Islam, 12(1), 173-201.

Saihu, M. (2019). Merawat Pluralisme Merawat Indonesia (Potret Pendidikan Pluralisme Agama Di Jembrana-Bali). Deepublish.

Saihu, M. M., \& Aziz, A. (2020). Implementasi Metode Pendidikan Pluralisme Dalam Mata Pelajaran Pendidikan Agama Islam. Belajea; Jurnal Pendidikan Islam, 5(1), 131-150.

Saihu, S. (2019). IMPLEMENTASI MANAJEMEN BALANCED SCORECARD DI PONDOK PESANTREN JAM'IYYAH ISLAMIYYAH TANGERANG SELATAN. Mumtaz: Jurnal Studi Al-Quran dan Keislaman, 3(1), 1-22.

Saihu, S. (2019). KOMUNIKASI PENDIDIK TERHADAP ANAK BERKEBUTUHAN KHUSUS DI SEKOLAH KHUSUS ASY-SYIFA LARANGAN. Andragogi: Jurnal Pendidikan Islam dan Manajemen Pendidikan Islam, 1(3), 418-440.

Saihu, S. (2019). KONSEP MANUSIA DAN IMPLEMENTASINYA DALAM PERUMUSAN TUJUAN PENDIDIKAN ISLAM MENURUT MURTADHA MUTHAHHARI. Andragogi: Jurnal Pendidikan Islam dan Manajemen Pendidikan Islam, 1(2), 197-217.

Saihu, S. (2019). PENDIDIKAN KARAKTER BERBASIS KEARIFAN LOKAL (STUDI DI JEMBRANA BALI). Edukasi Islami: Jurnal Pendidikan Islam, 8(01), 69-90.

Saihu, S. (2019). Pendidikan Pluralisme Agama: Kajian tentang Integrasi Budaya dan Agama dalam Menyelesaikan Konflik Sosial Kontemporer. Jurnal IndoIslamika, 9(1), 67-90,

Saihu, S. (2019). RINTISAN PERADABAN PROFETIK UMAT MANUSIA MELALUI PERISTIWA TURUNNYA ADAM AS KE-DUNIA. Mumtaz: Jurnal Studi Al-Quran dan Keislaman, 3(2), 268-279,

Saihu, S. (2020). ETIKA MENUNTUT ILMU MENURUT KITAB TA'LIM MUTA'ALIM. Al Amin: Jurnal Kajian Ilmu dan Budaya Islam, 3(1), 99-112.

Saihu, S. (2020). KONSEP PEMBAHARUAN PENDIDIKAN ISLAM MENURUT FAZLURRAHMAN. Andragogi: Jurnal Pendidikan Islam dan Manajemen Pendidikan Islam, 2(1), 82-95.

Saihu, S. (2020). Pendidikan sosial yang terkandung dalam Surat At-Taubah Ayat 71-72. Edukasi Islami: Jurnal Pendidikan Islam, 9(01), 127-148.

Saihu, S. (2020). The Effect of Using Talking Stick Learning Model on Student Learning Outcomes in Islamic Primary School of Jamiatul Khair, Ciledug Tangerang. Tarbawi: Jurnal Keilmuan Manajemen Pendidikan, 6(01), 6168. 
Saihu, S., \& Mailana, A. (2019). Teori pendidikan behavioristik pembentukan karakter masyarakat muslim dalam tradisi Ngejot di Bali. Ta'dibuna: Jurnal Pendidikan Islam, 8(2), 163-176.

Saihu, S., \& Marsiti, M. (2019). PENDIDIKAN KARAKTER DALAM UPAYA MENANGKAL RADIKALISME DI SMA NEGERI 3 KOTA DEPOK, JAWA BARAT. Andragogi: Jurnal Pendidikan Islam dan Manajemen Pendidikan Islam, 1(1), 23-54.

Saihu, S., \& Rohman, B. (2019). PEMBENTUKAN KARAKTER MELALUI MODEL PENDIDIKAN TRANSFROMATIFE LEARNING PADA SANTRI DI PONDOK PESANTREN NURUL IKHLAS BALI. Edukasi Islami: Jurnal Pendidikan Islam, 8(02), 435-452.

Saihu, S., \& Taufik, T. (2019). PERLINDUNGAN HUKUM BAGI GURU. $A l$ Amin: Jurnal Kajian Ilmu dan Budaya Islam, 2(2), 105-116. 